INTERACTION: Jurnal Pendidikan Bahasa: Vol. 6, No. 2: Oktober 2019

ISSN: 2406-9558; E-ISSN: 2406-9566

\title{
The Student's Ability in Using Punctuation and Capitalization through Performing Habit of Writing Diary
}

\author{
Siti Nurhayati \\ sitinurhayati@gmail.com \\ SMP Guppi Salawati
}

\begin{abstract}
In this study, the writer chose the students ability in using punctuation and capitalization through performing habit of writing diary at the second grade of SMP GUPPI Salawati. For that reason the writer wants to investigate and doing research in the library. The formulation of problem in this research are How is the students competence in apply writing mechanism, and what is the effect of performing habit of writing diary to increase students skill in writing mechanism. The methodology of this study is experimental study. it is means that its need statistic approach to explore the material. There are some of technique of collecting data such as the researcher after developing the test as the instrument of the research, asked the sample (students) to complete the text with punctuation, After they handed their works the writer checked the punctuation they had applied in the given text, and the writer analyze the comments or the mistake they made based on the theory. The result of this study is the writer found that teaching writing mechanism by performing habit of writing diary better than without performing habit of writing diary. It means that the students are more interest to write with writing diary and without writing diary.
\end{abstract}

Keywords: students ability, performing habit, writing diary.

\section{INTRODUCTION}

Writing skill are more complex and difficult to teaching, requiring, and mastering not only of grammatical and rhetorical devices but also conceptual and judgment, because of the difficulties of writing, some efforts have been done to solve the problem. We also must pay attention to the grammar, so it is normal if Study English sometimes is still difficult, because the rule is not exactly same with our language.

Understanding writing mechanism like capitalization, punctuation, and spelling is not easy although in fact the students still difficulty to use writing mechanism by putting the elements as well as the correct use of spelling in the text or sentences that are customized by spelling in polishing.

Performing habit of writing diary is an activity of person's in making handwriting book that used for a daily record or event and its do often and almost without thinking. We can see adult really likes writing diary because Writing diary is fun because in writing 
INTERACTION: Jurnal Pendidikan Bahasa: Vol. 6, No. 2: Oktober 2019

ISSN: 2406-9558; E-ISSN: 2406-9566

diary students don't needs concentration, imagination, and hard thinking only enough with bring outside our felling that has happened.

Performing a habit of writing diary must be done in teaching process and learning because internalizing habit takes much time. Based on the statement above the writer will investigate performing habit of writing diary to increase student competence in apply writing mechanism.

\section{LITERATURE REVIEW}

\section{Previous of Study}

Makhisoh, Iis. 2010. Using Free Writing Technique to Improve Students' Writing of The Language Program at Madrasah Aliyah Negeri Tambakberas Jombang. Thesis, Arabic Department, Faculty of Letters, State University of Malang. The Supervisor: Drs. M. Syatibi Nawawi, M.Pd. Being afraid of making linguistic errors and feeling hard to express ideas made students of Madrasah Aliyah Negeri Tambak Beras Jombang think that writing is difficult, that is the result of interview and questionnaires.

\section{METHOD}

\section{Design}

This study is an experimental research, since it describes the quantitative degree in which variable are related. It is also reasonable that the writer intend to examine the cause and effect between two variables, performing habit of writing diary and student competence in apply writing mechanism.

The design is called a pre-test and post-test control group design. The study design is adopted from Ary, et.al (2002: 308) as follows:

Table 1.The Experimental Research Design

\begin{tabular}{|l|l|l|l|l|}
\hline Group & Random & Pre test & Treatment & Post test \\
\hline E & R & O1 & X & O2 \\
\hline C & R & O3 & & O4 \\
\hline
\end{tabular}

Notes :

$\mathrm{E}=$ experimental group

$\mathrm{C}=$ control group

$\mathrm{O} 1=$ pre-test experimental group

$\mathrm{O} 3=$ pre test control group

$\mathrm{O} 2=$ post test experimental group

$\mathrm{O} 4=$ post test control group 
INTERACTION: Jurnal Pendidikan Bahasa: Vol. 6, No. 2: Oktober 2019

ISSN: 2406-9558; E-ISSN: 2406-9566

$X=$ treatment which the writer give to experimental group by writing diary

\section{Analysis Data}

To find out the result of the test, the writer uses some statistic and takes steps as follow.

a. Identifying the students` mistake by reading the students worksheet one by one. In reading the writer would identify the mistakes retelling to mechanics.

b. Giving the score, in determining this, the writer would find the percentage of each problem type.

Table 2. The Criteria of Writing Element

\begin{tabular}{|l|l|l|}
\hline No & The element of written & Score \\
\hline 1 & Content & $1-30$ \\
\hline 2 & Grammar & $1-25$ \\
\hline 3 & Organization & $1-20$ \\
\hline 4 & Vocabulary & $1-20$ \\
\hline 5 & Mechanic & $1-5$ \\
\hline & Total score & 100 \\
\hline
\end{tabular}

(Brown, 2004:246)

To interpret the result of the students` worksheet, the writer used statistical procedures as follows:

Mean

The mean is the average of group scores. The way to compute the mean is adding all the students` scores then dividing this sum by the number of the test takers. The formula used to compute the mean is as follows:

a. Mean $(X)$

$X=\frac{\sum X}{N}$

Where:

$\mathrm{X}:$ Mean

$\Sigma x:$ Sum of Any Test Score

$\mathrm{N}$ : Sample

\section{RESULT AND DISCUSSION}

\section{Students`Ability Taught by the habit of writing diary}

The students` ability taught by the habit of writing diary is very good. Through habit writing diary that the writer used in experimental class, it can be known the score of 
INTERACTION: Jurnal Pendidikan Bahasa: Vol. 6, No. 2: Oktober 2019 ISSN: 2406-9558; E-ISSN: 2406-9566

each student in performing habit writing diary to increase students competences in apply writing mechanism. It can be seen from the score of pre-test and post-test as follows

Table 5.The Students' Score of Experimental Class

\begin{tabular}{|l|l|l|l|}
\hline No & Name of Students & Pre - test & Post - test \\
\hline 1. & A.K.P & 60 & 70 \\
\hline 2. & E.S & 65 & 75 \\
\hline 3. & F.H & 60 & 74 \\
\hline 4. & I.B & 56 & 73 \\
\hline 5. & M.E.T & 60 & 75 \\
\hline 6. & N.N & 64 & 80 \\
\hline 7. & N.P & 73 & 88 \\
\hline 8. & R.Y & 65 & 79 \\
\hline 9. & S.K & 61 & 71 \\
\hline 10. & W.W & 55 & 80 \\
\hline & Total score & 619 & 765 \\
\hline & Average & 61,9 & 76,5 \\
\hline
\end{tabular}

Based on the result of the pre-test and post-test that the students did, it can be concluded that the average score of pre-test was 61,9. The highest score was 73 and the lowest score was 55. After the writer got the result of the students' score, then she calculated their percentage in improving writing recount text ability. To obtain the percentage of the students' letter grade, the writer applied them into the following formula:

Table 6. The percentage of the students' writing mechanism Grade Pre-test Percentage

\begin{tabular}{|l|l|c|}
\hline Grade & Pre- test & Percentage \\
\hline Excellent & - & - \\
\hline Very good & - & - \\
\hline Good & 1 & $10 \%$ \\
\hline Fair & 4 & $40 \%$ \\
\hline Poor & 5 & $50 \%$ \\
\hline Very poor & - & - \\
\hline $\begin{array}{l}\text { Total } \\
\text { students }\end{array}$ & 10 & $100 \%$ \\
\hline
\end{tabular}

P: $\underline{F} \times 100 \%$

$\mathrm{N}$ 
Based on the result above, it can be known that there were $100 \%$ students mastered on writing mechanism taught by habit writing diary.

Based on the result above, it can be said that there were $100 \%$ of the students who mastered writing recount text without using photographs, but there were a decrease of the ability of writing recount text. It can be known from the result of the percentage after given treatment in control class was not successful.

\section{Students Competences in Apply writing Mechanism Without performing habit writing diary.}

Table 7. The Students' Score of Control Class

\begin{tabular}{|l|l|l|l|}
\hline No & Name of Students & Pre - test & Post- test \\
\hline 1. & L.H & 55 & 60 \\
\hline 2. & A.N & 65 & 53 \\
\hline 3. & T.H & 70 & 75 \\
\hline 4. & S.N & 51 & 60 \\
\hline 5. & N.S & 70 & 60 \\
\hline 6. & A.D & 60 & 72 \\
\hline 7. & E.R & 55 & 70 \\
\hline 8. & T.T & 60 & 55 \\
\hline 9. & R.T & 60 & 67 \\
\hline 10. & E.K & 52 & 63 \\
\hline & Total score & 599 & 635 \\
\hline & Avery & 59.99 & 63.50 \\
\hline
\end{tabular}

Based on the result of the pre-test and post-test that the students did, it can be concluded that the average score of pre-test was 60.40 . The highest score was 70 and the lowest score was 51. It means that teaching writing mechanism text without writing diary in control class was not successful.

After the writer got the result of the students' score, then she calculated their percentage in improving writing recount text ability.

Table 8. The Percentage of The Students' Writing Mechanism Grade Pre-Test Percentage

\begin{tabular}{|l|c|c|}
\hline Grade & Post- test & Percentage \\
\hline Excellent & - & - \\
\hline Very good & 1 & $10 \%$ \\
\hline Good & 8 & $80 \%$ \\
\hline Fair & 1 & $10 \%$ \\
\hline Poor & - & - \\
\hline Very poor & - & - \\
\hline
\end{tabular}


INTERACTION: Jurnal Pendidikan Bahasa: Vol. 6, No. 2: Oktober 2019

ISSN: 2406-9558; E-ISSN: 2406-9566

\begin{tabular}{|l|l|l|}
\hline Total students & 10 & $100 \%$ \\
\hline
\end{tabular}

To obtain the percentage of the students' letter grade, the writer applied them into the following formula:

$\mathrm{P}: \underline{F} \times 100 \%$

$\mathrm{N}$

Based on the result above, it can be said that there were $90 \%$ of the students who mastered writing mechanism by performing habit diary, but there were a decrease of the apply writing mechanism. It can be known from the result of the percentage after given treatment in control class was not successful

Significance of Different between Students' Competences in Apply Writing Mechanism Who are Taught by Performing Habit of Writing diary.

It can be seen from the result of the final score or post-test that the used to measure the improvement of their ability in writing mechanism.

The average score of post-test of experimental class after they were given treatment:

$$
\begin{aligned}
X & =\frac{\sum X}{N} \\
& =\frac{765}{10} \\
& =76.5
\end{aligned}
$$

The average scores of the students ability in writing mechanism by habit of writing diary is 76.5 . The figure is then consulted to the following

Table 9. Criteria of Mastery Grade

\begin{tabular}{|l|l|}
\hline Criteria of mastery & Grade \\
\hline $91-100$ & Excellent \\
$81-90$ & Very good \\
$71-80$ & Good \\
$61-70$ & Fair \\
$51-60$ & Poor \\
less than 50 & Very poor \\
& \\
\hline & \\
\hline
\end{tabular}

It can be seen that the 63.5 is on the rage $61-70$ which is categorized into fair. To find out the differences between the students` ability in writing recount text by using photographs and without using photographs the writer uses T-test formula. The T-test which is used in this research is as follows: Where: 
INTERACTION: Jurnal Pendidikan Bahasa: Vol. 6, No. 2: Oktober 2019

ISSN: 2406-9558; E-ISSN: 2406-9566

Mx: Mean Deviation of Experimental Class

$\mathrm{M} Y$ : Mean Deviation of Control Class

$\Sigma \times 2$ :Deviation of Each Post Test Score from Pre Test of

Experimental Class

$\Sigma$ y2 :Deviation of Each Post Test Score from Pre Test of Control Class

Before computing the t-test above, the writer did some steps as follows:

a. Finding Out the Mean of Deviation of Experimental Class (Mx)

b. Finding Out the Mean of Deviation of Control Class (My)

c. Finding Out the Deviation of Each Post Test from Pre Test Source of Experimental Class $\left(\sum x 2\right)$

d. Finding Out the Deviation of Each Post Test from Pre Test Source of Control Class $\left(\sum y 2\right)$

e. The Last Steps of The Hypothesis Testing is T- test

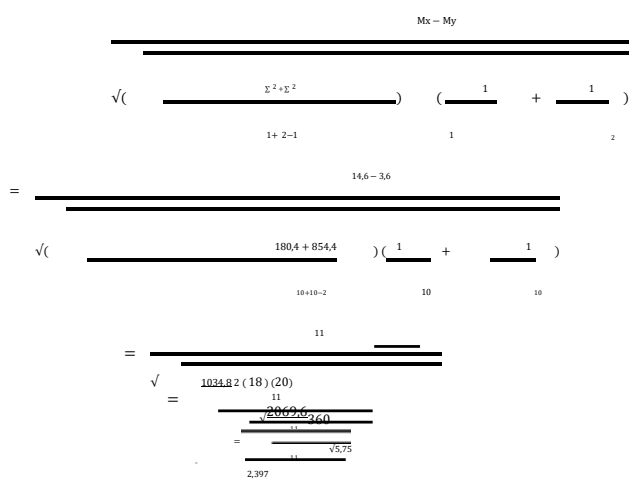

From the result of calculation above, the total t- obtained value of the research is 4.58 with that degree of freedom (df) is (20+20)-2=18 and level of significant 5\%(0. 05), so the value table of t-table is 1. 98). The calculation shows that t-obtained value higher than t-table.

\section{Post Test}

After getting the results of the data calculation, the researcher feels satisfy about the students` developmental score. In the pre test, the result score and included to fair in 
INTERACTION: Jurnal Pendidikan Bahasa: Vol. 6, No. 2: Oktober 2019

ISSN: 2406-9558; E-ISSN: 2406-9566

the level of average achievement but in the post test, the result shows76,8 and included to good in the level above average, so the treatment and also the instrument are really helped the students to improve writing recount text by using photographs . The problem which are faced in doing pre -test:

a. In the pre test almost of the students are not ready to write and do the test to express their words in English are very difficult and not all of them bring the dictionary.

b. The students do not master and understand the English grammar well.

c. The students do not master English vocabulary well, especially in choosing the appropriate words to their story

d. The student do not really master mechanic

\section{Discussion}

According to the research finding, the writer found that teaching writing mechanism by performing habit of writing diary better than without performing habit of writing diary. It meant that the students are more interest to write with writing diary and without writing diary.

a. Students` Ability Taught by performing habit of writing diary. The students ability taught by performing habit of writing diary is very good. The average scores of the students achievement who were taught by performing habit of writing diary was 76.5 . It is included in the good categorized.

b. Students` Ability Taught Without performing habit of writing diary. The result of the students`ability taught without performing habit of writing diary was fair. The average score of written test was 63.5. It can be seen that the 63.5 was on the range 61-70which is categorized into fair.

c. Significance of Different of the students`ability in writing mechanism by Performing habit of writing diary and without performing habit of writing diary The writer found that there was significant difference between the students' ability in writing mechanism who were taught by performing habit of writing diary and those taught without could performing habit of writing diary.

It meant that writing diary help the students in improving their skill in writing mechanism. It can also help the teacher to improve the students motivation and interest in writing mechanism according to the writing diary. Teaching by using writing diary was better that without it.

\section{CONCLUSION}

From the discussion in the previous chapters, some points can be concluded as follows:

a. The average score of the students who were taught writing mechanism by Performing habit of writing diary is 76.5 .

b. The average score of the students who were taught writing mechanism without by performing habit of writing diary is 63.5. 
INTERACTION: Jurnal Pendidikan Bahasa: Vol. 6, No. 2: Oktober 2019 ISSN: 2406-9558; E-ISSN: 2406-9566

c. The $\mathrm{t}$-test level significant $\mathrm{t} 0.05$ shows that $\mathrm{t}$ - obtained value is 12.85 and $\mathrm{t}$-table value is 1.98 , so there is a significant difference in the students 'achievement between those who were taught writing mechanism by performing habit of writing diary and those who were taught writing mechanism without performing habit of writing diary.

\section{REFERENCES}

Anderson, M. and Anderson, K. 1998. Text Types in English 3.South Yarra: MacMillan.

Barjesteh, H., Vaseghi, R., and Gholami R. 2011. The Effect of Diary Writing on EFL College Students' Writing Improvement and Attitudes. International Conference on Languages, Literature and Linguistics IPEDR vol.26 (2011).

Bell, J. 2005. Doing Your Research Project-4thEdition: A Guide for First-time Researchers, in Education, Health and Social Sciences. Berkshire: Open University Press.

Brown, D.H. 2003. Language Assessments: Principles and Classroom Practices.New York: Longman.

Brown, Douglas. H. 2000. Principles of Language Learning and Teaching. London: Addison Wesley .Longman. 2001. Teaching by Principles:An Interactive Approach to Language Pedagogy2nd Edition. New York: Longman.

Burns, A. 1999. Collaborative Action Research for English Language Teachers. Cambridge: Cambridge University Press.

Curtis, A. and Bailey, K.M. 2007. "Research Digest: Diary Study". On CUE Journals, Vol.3, No.1, pp. 67-85.

Depdiknas. 2006. Kurikulum 2006: Standar Kompetensi Mata Pelajaran.Jakarta: Depdiknas.

Fitzpatrick, M. 2005. Engaging Writing Paragraph and Essay. London: Longman. Harmer, J. 2007. The Practice of English Language Teaching-4thEdition. London: Longman.. 2004. How to Teach Writing. London: Longman.. 2001. The Practice of English Language Teaching-3rdEdition. London: Longman.

Kemmis, S and McTaggart, R. 1998. The Action Research Planner. Victoria: Dankin University.

Langan, J. 2011. College Writing Skills with Readings-International Edition 8thEdition. New York: McGraw-Hill, Inc.74. 2008. College Writing Skills with Readings-7th Edition. New York: McGrawHill, Inc. 2005. College Writing Skills with Readings-6th Edition. New York: McGrawHill, Inc. 
INTERACTION: Jurnal Pendidikan Bahasa: Vol. 6, No. 2: Oktober 2019 ISSN: 2406-9558; E-ISSN: 2406-9566

Makhisoh, Iis. 2010. Using Free Writing Technique to Improve Students' Writing of The Language Program at Madrasah Aliyah Negeri Tambak Beras Jombang.

Masiello, Lea. 1986. Writing in Action. New York: MacMillan Publishing Company.

Mc Carthy, Michael. 2000. Discourse Analysis for Language Teachers. Cambridge: Cambridge University Press.

Mc Donald, C.R. and McDonald, R.L. 2002. Teaching Writing. America: Southern Illinois University Press.

Miles, M.B., and Huberman, A.M. 1994. An Expanded Sourcebook: Qualitative Data Analysis-2nd Edition. London: Sage Publication, Ltd.

Nation, I.S.P. 2009. Teaching ESL/EFL Reading and Writing.New York: Routledge.

Oshima, A. and Houge, A. 2006. Writing Academic Essay: Forth edition. White Plains: Longman.

Richards, J.C., and Renandya, W. A.. 2002. Methodology in Language Teaching: An Anthology of Current Practice. Cambridge: Cambridge University Press.

Stanley, L.C., Shimkin, D., and Lanner, A.H.. 1988. Ways to Writing: Purpose, Task, and Process-2nd Edition. New York: MacMillan Publishing Company.

Suharto, G. 2006. Pengukuran dan Penilaian Hasil Belajar Bahasa Inggris. Yogyakarta: P3B UNY.

Tuan, L.T. 2010. "Enhancing EFL Learners" Writing Skills via Journal Writing”. English Language Teaching Journal, Vol.3, No. 3, pp. 81-88.

Weigle, S.C. 2002. Assessing Writing. Cambridge: Cambridge University Press. 